\title{
10. Education cost rapid assessment post check
}

\section{PART I. BACKGROUND AND CONCEPTUAL FRAMEWORK}

Education is considered to be a human right in the world today. The right to education is part of the 1948 United Nations Declaration of Human Rights, the 1959 Declaration of the Rights of the Child, and the 1966 International Covenant on Economic, Social and Cultural Rights. Because of this, a post check is done to make sure that sufficient funds are included in non-food non-housing costs (NFNH), and therefore in the living wage, to enable workers to send their children to school.

This chapter describes how to do a rapid post check to make sure that a living wage includes sufficient funds for children's education. When the amount included in NFNH is substantially less than the cost of education for children according to a rapid assessment, the preliminary estimate of NFNH is increased. Note that since this is a rapid assessment, an increase should be made only when there is a large difference, because rapid assessments by their very nature are only approximate.

Education post check adjustments are generally particularly important in countries where school attendance is low. This is because household expenditure data from household surveys reflect actual expenditure rather than household needs. When many children do not go to school, household survey expenditure data would indicate low expenditures by households for education.

\section{PART II. APPROACH TO EDUCATION COST POST CHECK}

Part II describes how to do an education rapid assessment cost post check. Determining the amount implicitly included in NFNH for education is more complex than for health care, because most government statistical offices classify educational expenditures differently from the way that laypersons think of education costs. The cost of school books and supplies 
is generally included in the cultural expenditure group rather than in the education expenditure group; and cost of school uniforms is generally included in the clothing and footwear expenditure group.

\subsection{Primary and Secondary Education for Children of Workers Assumed Necessary for Decency}

For decency, we feel that a living wage should be sufficient to enable children of workers to attend primary and secondary school. Achieving primary education is an United Nations Millennium Development Goal. While attending secondary school is not a Millennium Development Goal, secondary school attendance is the norm in most countries. The net secondary school enrollment rate was $66 \%$ worldwide in 2013, ranging from 33.7\% in Sub-Saharan Africa to 77.1\% in East Asia and the Pacific developing countries (World Bank, 2016).

\subsection{Usually Assume Children Attend Public School}

It is almost always appropriate to assume that children attend state/public school and that attendance at private school is not required for basic decency (unless public school is not available). Data are generally available from household surveys and the World Bank World Development Indicators database on the percentage of school children who attend private school. At the same time, it is necessary to keep in mind that the line between public and private education is not as clear as the dichotomy implies, because many 'private schools' receive public funding, and many 'public schools' expect contributions from households.

\subsection{Key Aspects of Education System}

Key features of the education system in the country should be succinctly indicated in a living wage report. This is especially important for international readers. Number of standards and official ages for primary school and secondary school help set the stage for understanding the education system. This is usually common knowledge and is available on the UNESCO website.

Information on net primary school and net secondary school enrollment rates in the country ${ }^{1}$ should be disaggregated when possible by gender, rural and urban areas, and income quintile, because there are often large differences (especially for secondary education) by location, gender and income. These differences tend to be greater, the farther away a country is from the target of universal education. Information on enrollment rates 
is very useful for understanding the extent to which current household expenditures for education in national statistics reflect needs. When the secondary school enrollment rate is low, the amount spent on education according to household surveys will be much lower than the amount needed to educate children through secondary school.

For primary education according to UNICEF (2015): 'more than half of countries and areas worldwide have achieved or nearly achieved universal primary education - that is, they have a net enrolment rate or net attendance rate of more than 95 per cent. In about 20 countries, however, net enrolment or attendance is less than 80 per cent. These countries are concentrated mainly in West and Central Africa and in South Asia, and many of them are affected by conflict.' For secondary education, the UNICEF (2015) website contains relevant information by gender, location, and income for most countries. Academic journal articles can also provide useful information.

In addition to reporting rural and urban school enrollment rates, it is useful but not required for a living wage report to discuss common problems with public schools such as high repeater rates and low continuation rates as well as other indicators of the quality of education such as class sizes, student-teacher ratios, availability of textbooks, and availability of basic services in schools such as electricity, potable water, and adequate sanitation. This type of information can be found on the World Bank, UNESCO and UNICEF websites as well as from journal articles and DHS reports. The UNESCO website has a special data set for Sub-Saharan Africa that includes indicators of educational quality.

\subsection{How to Calculate Amount Included for Education in Preliminary Estimate of NFNH Costs}

The amount implicitly included for education in the preliminary estimate of NFNH costs is determined using secondary household survey data. The percentage spent on education relative to all NFNH expenditure is multiplied by the preliminary estimate of NFNH costs. For example, if education expenditure is $5 \%$ of all NFNH expenditure according to household expenditure data and the preliminary estimate of NFNH costs is 100 , then the preliminary estimate of funds included for education in the preliminary estimate of NFNH would be $50(5 \% \times 100)$. 


\subsection{How Education Expenditures Are Classified in Household Expenditure Statistics}

\subsubsection{Classification of Individual Consumption according to Purpose (COICOP)}

Most countries use Classification of Individual Consumption according to Purpose (COICOP) to classify household expenditures. In this classification, education (expenditure group 10) only includes expenditures for educational services (such as school fees and teacher tutoring). 'It [COICOP] does not include expenditures on educational materials such as books (09.5.1) and stationary (09.5.4), or educational support services such as health care services (06), transportation services (07.3), catering services (11.1.2), and accommodation services (11.2.0)' (ILO et al., 2004 , p. 479). Nor are school uniforms, jackets and bags considered to be education expenditure in COICOP as they are included in the clothing expenditure group. This means that a considerable part of what households spend for children's schooling does not appear as educational expenditures in CIOCOP and therefore expenditure statistics for most countries understate the amount that households actually spend on education because of how COICOP is structured. ${ }^{2}$ Rural Dominican Republic and rural Malawi provide examples of this, as according to household expenditure survey data only $1.0 \%$ is spent on education in rural Dominican Republic and only $1.5 \%$ is spent on education in rural Malawi despite the considerable educational expenses for households in these countries as we found in living wage studies for these countries.

\subsubsection{Other national classifications of household expenditures}

Some countries deviate from COICOP and use a more comprehensive education expenditure group. This is done in order to better measure household well-being. When this happens, a more realistic percentage of household expenditures for education is found. In Kenya and Vietnam, for example, $5.9 \%$ of reported household expenditures are for education. ${ }^{3}$ Detailed information for Vietnam on the percentage distribution of education expenditures is informative: textbooks $(6.8 \%)$, uniforms $(5.2 \%)$, study tools $(5.7 \%)$, school fees $(33.1 \%)$, school fund $(8.2 \%)$, extra classes $(11.1 \%)$, and other costs that include tutoring $(28.4 \%)$. These data show that education services and fees (that are included in education in COICOP) comprise around $80 \%$ of education costs for households in Vietnam. 


\subsubsection{Implications of different household expenditure classifications for measuring education expenditures}

The implication of the above discussion on classifications used for education expenditures is that reported percentages of household expenditures for education across countries differ partly because of the classification used for household expenditures. A classification can be fairly comprehensive and yield realistic estimates of education spending by households (e.g. Kenya and Vietnam), or a classification can be narrow and yield unrealistically low estimates of education expenditure (e.g. Malawi and the Dominican Republic, which follow COICOP). This means that care is required when deciding whether additional funds should be added for education to the preliminary estimate of NFNH costs.

In order for the comparison between education costs from a rapid education post check and the estimate of education funds included in the preliminary estimate of NFNH costs to be comparable, the types of educational expenditures included in a rapid post check should be as similar as possible to the types of educational expenditures included in the classification used to measure education expenditures in secondary household expenditure data.

\subsection{Estimating Education Costs}

Most governments theoretically provide free primary and secondary education. However, there are often significant education costs for households even when education is theoretically free. Households pay for different fees and services in different countries so that a list of education costs needs to be country-specific. Education costs often include some or all of the following expenses:

1. School fees each semester and one-time registration fees. School fees are often especially important for secondary school.

2. Uniforms and equipment. It is common for schools to require students to wear school uniforms and for students to need a school bag to carry books to and from school.

3. Learning materials such as textbooks, exercise books, and other stationary supplies including pens and pencils.

4. Supplementary tutoring. In some countries, school children (especially in secondary school) require supplementary tutoring in order to advance properly in their studies. This functions as a shadow system to help support teacher salaries (Bray, 2007). Supplementary tutoring is often required for students - even good students - to advance. We found these costs to be considerable in living wage studies for Kenya, 
Vietnam, and Mauritius. Bray and Bunley (2005) found this for Cambodia.

5. Tests and examinations. Fees for examinations are common in many countries. We found such fees even in kindergarten in Kenya.

6. Transport. Costs for transport to and from school are common, especially for secondary school.

7. Other expenses. There are often various other expenses associated with public education such as PTA contributions, teacher motivation fees, personal gifts to teachers, and fees associated with school cleaning, heating, and maintenance.

The cost of public education for households varies enormously by country. According to an article published by UNESCO: 'In some settings all inschool costs are met by the government, and the out-of-school costs, uniforms, transport, etc. are so small that they are not thought by analysts to deserve much attention... . In other settings, household and community expenses are so large that they comprise over half the total, even in public systems of education. Cambodia is one country in this category.' (Bray, 1999). Other countries cited in the same publication where more than half of total primary public education expenditure was paid for by households included Myanmar, Togo, Uganda, and Vietnam.

Unfortunately, there are no international databases that indicate costs to households for public education. Nor is this well-researched, even though expenses associated with school attendance are especially high for poor parents in many countries. Therefore, to determine education cost to parents, it is necessary to draw up a list of typical education costs by level, and then find out how much workers typically pay for each type of expense from key informants, focus group discussions, and discussions with workers, and possibly from discussions or written questionnaires filled out by parents and/or school officials such as principals, teachers and administrators.

\subsubsection{Gathering information on costs of children's education}

Table 10.1 is a dummy table to record typical household education expenses for children in public schools and to calculate the annual cost of education per child and per reference size family. This table should be adapted to reflect the types of local school costs paid by households. Since this table records annual costs, expenses per month or per semester should be converted into annual costs.

The last column of Table 10.1 indicates whether or not an expense is classified under the education expenditure group in national household expenditure statistics. National statistical offices almost always publish a 
Table 10.1 Table of typical annual household costs for school per student by level (list of expenses should be country-specific)

\begin{tabular}{|c|c|c|c|c|c|}
\hline Type of expense & $\begin{array}{l}\text { Pre- } \\
\text { primary } \\
\text { (when } \\
\text { common) }\end{array}$ & Primary & $\begin{array}{l}\text { Lower } \\
\text { secondary }\end{array}$ & $\begin{array}{l}\text { Upper } \\
\text { secondary }\end{array}$ & $\begin{array}{l}\text { Classified } \\
\text { under } \\
\text { education } \\
\text { in national } \\
\text { expenditure } \\
\text { statistics? } \\
\text { (Yes or No) } \\
\end{array}$ \\
\hline \multicolumn{6}{|l|}{ Registration fees } \\
\hline \multicolumn{6}{|l|}{ School fees } \\
\hline \multicolumn{6}{|l|}{$\begin{array}{l}\text { School funds such as } \\
\text { building fund }\end{array}$} \\
\hline \multicolumn{6}{|l|}{$\begin{array}{l}\text { Fees for typical extra } \\
\text { activities and materials } \\
\text { (e.g. art supplies, } \\
\text { physical education } \\
\text { equipment) }\end{array}$} \\
\hline \multicolumn{6}{|l|}{$\begin{array}{l}\text { Supplemental tutoring } \\
\text { (when customary) }\end{array}$} \\
\hline \multicolumn{6}{|l|}{$\begin{array}{l}\text { Teacher appreciation/ } \\
\text { gifts }\end{array}$} \\
\hline \multicolumn{6}{|l|}{$\begin{array}{l}\text { School maintenance } \\
\text { (e.g. cleaning, utilities, } \\
\text { furniture) }\end{array}$} \\
\hline \multicolumn{6}{|l|}{ Examination fees } \\
\hline \multicolumn{6}{|l|}{ Uniforms } \\
\hline \multicolumn{6}{|l|}{ School bag } \\
\hline \multicolumn{6}{|l|}{$\begin{array}{l}\text { Learning materials } \\
\text { (e.g. books) }\end{array}$} \\
\hline \multicolumn{6}{|l|}{$\begin{array}{l}\text { School supplies } \\
\text { (e.g. notebooks, } \\
\text { pencils) }\end{array}$} \\
\hline \multicolumn{6}{|l|}{$\begin{array}{l}\text { Other expenses } \\
\text { specify: }\end{array}$} \\
\hline $\begin{array}{l}\text { Total of above expenses } \\
\text { when Yes in last column } \\
\text { (1) }\end{array}$ & & & & & \\
\hline
\end{tabular}


Table 10.1 (continued)

\begin{tabular}{|l|l|l|l|l|l|}
\hline Type of expense & $\begin{array}{l}\text { Pre- } \\
\text { primary } \\
\text { (when } \\
\text { common) }\end{array}$ & Primary & $\begin{array}{l}\text { Lower } \\
\text { secondary }\end{array}$ & $\begin{array}{l}\text { Upper } \\
\text { secondary }\end{array}$ & $\begin{array}{l}\text { Classified } \\
\text { under } \\
\text { education } \\
\text { in national } \\
\text { expenditure } \\
\text { statistics? } \\
\text { (Yes or No) }\end{array}$ \\
\hline $\begin{array}{l}\text { Number of years in } \\
\text { each level } \\
(2)\end{array}$ & & & & & \\
\hline $\begin{array}{l}\text { Total cost } \times \text { number of } \\
\text { years in each level } \\
(3)=(1) \times(2)\end{array}$ & & $\mathrm{X}$ & $\mathrm{X}$ & $\mathrm{X}$ & \\
\hline $\begin{array}{c}\text { Average cost per child } \\
\text { per year } \\
(4)=(3) \div 18\end{array}$ & & & & & \\
\hline $\begin{array}{c}\text { Average cost for reference } \\
\text { family per month } \\
\text { (5) }=(4) \times \text { number of } \\
\text { children in reference } \\
\text { family } \div 12\end{array}$ & & & & & \\
\hline
\end{tabular}

statistical glossary for their national classification of household expenditures. When summing up school cost in Table 10.1 only those costs that are classified as an educational expense in national statistics should be included, so that comparisons can be made to the educational expenses implicitly included in the preliminary NFNH estimate.

\subsubsection{Possibility that pre-primary school and/or nursery school is common and required for decency}

In some countries, it is customary for children to attend pre-primary school and/or nursery school. A judgment needs to be made as to how common it is for children to attend nursery/pre-primary school and so whether or not attendance at nursery/pre-primary school is necessary for decency. When attendance in pre-primary school is considered to be necessary for decency in a country, then the column for pre-primary education should be filled in Tables 10.1 and 10.2.

Table 10.2 provides a hypothetical example of how to calculate education cost for a family with two children using results from Table 10.1. 
Table 10.2 Hypothetical example of how to calculate average education cost per month for a family with two children

\begin{tabular}{|l|c|c|c|c|c|}
\hline $\begin{array}{l}\text { Type of } \\
\text { expense }\end{array}$ & $\begin{array}{c}\text { Nursery/ } \\
\text { pre-primary } \\
\text { (when } \\
\text { common) }\end{array}$ & Primary & $\begin{array}{c}\text { Lower } \\
\text { secondary }\end{array}$ & $\begin{array}{c}\text { Upper } \\
\text { secondary }\end{array}$ & Total \\
\hline $\begin{array}{l}\text { Total annual } \\
\text { cost per } \\
\text { student } \\
\text { (1) }\end{array}$ & 100 & 200 & 300 & 400 & \\
\hline $\begin{array}{l}\text { Number of } \\
\text { years in } \\
\text { each level } \\
(2)\end{array}$ & 4 & 6 & 3 & 3 & 3700 \\
\hline $\begin{array}{l}\text { Total annual } \\
\text { cost per } \\
\text { student } \times \\
\text { number of } \\
\text { years in level } \\
(3)=(1) \times(2)\end{array}$ & $4 \times 100=$ & $6 \times 200$ & $3 \times 300=$ & $3 \times 400=$ & $400+1200+$ \\
\hline $\begin{array}{l}\text { Average cost per } \\
\text { year per child } \\
(4)=(3) \div 18\end{array}$ & 400 & $=1200$ & 900 & 1200 & $900+1200=$ \\
\hline $\begin{array}{l}\text { Average cost for } \\
\text { reference } \\
\text { family per } \\
\text { month } \\
(5)=(4) \times \\
\text { Number of } \\
\text { children } \div \\
12\end{array}$ & & & & & $206 \times 2 \div 12$ \\
\hline
\end{tabular}

\subsection{Comparing Cost of Education with the Amount Included for Education in Preliminary Estimate of NFNH Costs}

Education costs from the rapid assessment should be compared with the amount included in NFNH costs for education. If costs from the rapid assessment are much greater than the amount included for education in the preliminary estimate of NFNH, then NFNH should be increased accordingly. To be practical and conservative, small differences should be ignored, in part because the post check is based on a rapid assessment that 
provides an approximate estimate of education costs and in part because a small adjustment could possibly be controversial and would be in any case inconsequential.

\subsection{Summary of Steps in Education Cost Post Check}

STEP 1. Gather background information on the education system in the country from local sources and secondary sources such as UNESCO, UNICEF, DHS, and academic journal articles.

STEP 2. List education expenses of families and indicate whether each education expense is included in the education expenditure group in the national classification of household expenditures. The national statistical office should have a glossary that indicates which expenditures are included in the education expenditure group in its classification of household expenditures.

STEP 3. Calculate amount implicitly included for education in the preliminary estimate of NFNH costs.

STEP 4. Gather information from workers and key informants about costs to families of sending children to school. The idea is to do a rapid assessment to approximate the cost of education to families. Since not all schools charge the same amount, information should be obtained from several sources. Exclude outliers when calculating average costs.

STEP 5. Calculate average education costs through secondary school for a reference size family based on information gathered in step 4.

STEP 6. Compare amount included for education in the preliminary NFNH estimate to the rapid assessment estimate of education costs for the reference size family, and increase the preliminary NFNH cost estimate when a large difference is found.

\section{PART III. EXAMPLES OF EDUCATION RAPID ASSESSMENT POST CHECKS}

\subsection{Example of Education Post Check Loosely Based on Rural Malawi}

\subsubsection{Background information on Malawi education system}

The educational system in Malawi has eight years of primary school (beginning at age 6) and four years of secondary school. Very few children attend private school. The net attendance rate for primary school was $84.6 \%$ with $89 \%$ of primary school students attending a government 
school. However, classes were generally extremely large. The student to teacher ratio in primary school was 83 and there was a high rate of teacher absenteeism.

Secondary school attendance rates were low. Only $8.8 \%$ of $14-17$-year-olds attended secondary school (National Statistical Office (NSO) and ICF Macro, 2011).

Pre-primary school was not common. Although some children went to nursery school, working parents generally rely on extended family members to care for their pre-primary age children.

\subsubsection{Cost of education to households in rural Malawi}

Despite the fact that government primary schools are theoretically free, families are expected to contribute towards running school. Focus group discussions with workers indicated the following costs of school per month for primary and secondary schools (Table 10.3). Teachers at local schools felt that these costs provided a reasonably accurate account of educational costs to parents.

\subsubsection{Comparing cost of education with amount included for education in preliminary estimate of NFNH costs}

Based on the above cost figures, we estimated that school expenses for a family with three children (the reference size family for rural Malawi) for children through secondary school would be around K1,212 per month (for expenses classified under education expenditure group in Malawi household expenditure statistics). This was K404 more than the K808 per month included for education in the preliminary estimate of NFNH costs. Finding a large difference was expected, since average education expenditures of households in Malawi are low because so few children go to secondary school.

In light of the above, K400 per month was added to our preliminary estimate of NFNH costs to ensure that sufficient funds are available to workers to cover children's educational expenses through secondary school at government schools.

\subsection{Example of Education Post Check Loosely Based on Lake Naivasha, Kenya Area}

\subsubsection{Background information on the Kenyan education system}

Desire for education is very strong in Kenya. Parents very much want their children to go to school in order to help prepare them for a better life. This desire was clearly reflected in discussions we had with workers and others. This is also reflected by fact that $17.2 \%$ of government budget and $6.7 \%$ 
Table 10.3 Typical annual household costs per public school student by school level for Malawi

\begin{tabular}{|c|c|c|c|c|}
\hline Type of expense & Primary & $\begin{array}{c}\text { Lower } \\
\text { secondary }\end{array}$ & $\begin{array}{c}\text { Upper } \\
\text { secondary }\end{array}$ & $\begin{array}{l}\text { Whether classified } \\
\text { as education in } \\
\text { national statistics } \\
\text { (Yes or No) }\end{array}$ \\
\hline School fees & Free & 12,000 & 14,000 & Yes \\
\hline $\begin{array}{l}\text { School funds such as } \\
\text { building fund/general } \\
\text { purpose fund }\end{array}$ & 600 & 1,000 & 1,000 & Yes \\
\hline Uniforms & 0 & 200 & 250 & No \\
\hline School bag & 25 & 25 & 25 & No \\
\hline $\begin{array}{l}\text { Learning materials } \\
\text { (e.g. books) }\end{array}$ & 1,350 & 2,000 & 2,500 & Yes \\
\hline $\begin{array}{l}\text { School supplies } \\
\text { (e.g. notebooks, pencils) }\end{array}$ & 120 & 150 & 200 & Yes \\
\hline Examination fees & & 1,000 & 1,500 & Yes \\
\hline Other expenses specify: & None & 0 & 0 & N/A \\
\hline $\begin{array}{l}\text { Total costs classified } \\
\text { under education in } \\
\text { national statistics } \\
\text { (Yes in last column) }\end{array}$ & 2,070 & 16,150 & 19,200 & \\
\hline Number of years in each level & 8 & 2 & 2 & \\
\hline Total costs $\times$ number of years & 16,560 & 32,300 & 38,400 & 87,260 \\
\hline $\begin{array}{l}\text { Average cost per child per year } \\
\text { assuming parents responsible } \\
\text { for children until age } 18\end{array}$ & & & & 4,848 \\
\hline $\begin{array}{l}\text { Average cost per family per } \\
\text { month for reference family } \\
\text { with three children }\end{array}$ & & & & $\begin{array}{l}4,848 \times 3 \div \\
12=1,212\end{array}$ \\
\hline
\end{tabular}

of GDP is spent on education in Kenya (World Bank, World Development Indicators, 2015a).

Kenya's educational system has eight years of primary school (beginning at age 6) and four years of secondary school. Primary school enrollment rates are high in Kenya. Almost all children attend primary school. Primary school net enrollment rate was $82 \%$ in 2009 and the primary school completion rate was 91\% in 2006 (World Bank, World Development Indicators, 2016b). Secondary school net enrollment rate was lower but 
still reasonably high at 50\% in 2009 (World Bank, World Development Indicators, 2016b).

In order to satisfy the grassroots demand for education, government abolished user fees for public primary school in 2003. While quickly increasing enrollment in primary school from $6,000,000$ to approximately $7,200,000$ just in the first year (Riddell, 2003), quality of education deteriorated. The average student to teacher ratio in primary school went from 32 in 1999 to 47 in 2010. In addition to large class sizes, UNICEF (2014) reported that school facilities often lacked desks and have inadequate latrines and insufficient water.

\subsubsection{Cost of education in Kenya}

Almost all students in Kenya go to a public school. ${ }^{4}$ It is therefore reasonable to expect children of workers earning a living wage to attend public school and not private school. Many workers sent their children to nursery school. Therefore, we included two years of pre-primary school in our calculations.

During focus group discussions, workers expressed that school costs are of great concern. Workers mentioned having to pay sometimes or always for: school uniforms, sweaters, socks and shoes; exercise books and textbooks; exam fees; activity fees; teacher motivation fees; district education fee; one-time admission fee. Newspaper articles mention that parents are paying fees for secondary school, even though secondary school fees were formally abolished in 2009 (Howden, 2014).

Information on school costs indicated by workers in focus group discussions ranged from around $\mathrm{KSh} 3,000$ to $\mathrm{KSh} 7,500$ per year for primary school per year and from around KSh10,000 to KSh24,000 per year for secondary school. Although these were only a few approximate estimates, they were consistent with amounts mentioned in recent newspaper articles. They indicated costs of roughly KSh5,000 per year for pre-primary and primary school and around KSh14,500 per year for secondary school around KS6,000 per child per year when averaged over 18 years of childhood.

\subsubsection{Comparing costs for education with amount included for education in preliminary estimate of NFNH costs}

Our preliminary estimate of NFNH costs included KSh1,466 per month for education. This was similar enough to the rapid assessment estimate of education costs of KSh1,509 that we did not make any adjustment. 
Table 10.4 Typical annual household costs per student for public school by level for Lake Naivasha area of Kenya

\begin{tabular}{|c|c|c|c|c|}
\hline Type of expense & Pre-primary & Primary & Secondary & $\begin{array}{c}\text { Classified as } \\
\text { education in } \\
\text { national statistics? }\end{array}$ \\
\hline District education fee & & 1,000 & & Yes \\
\hline $\begin{array}{l}\text { One-time admission } \\
\text { fee (prorated to cost } \\
\text { per year) }\end{array}$ & & 100 & & \\
\hline School fees & 4,000 & 0 & 8,000 & Yes \\
\hline School funds & & 500 & & Yes \\
\hline Uniforms & 750 & 750 & 750 & Yes \\
\hline School bag & & 100 & 100 & Yes \\
\hline Books & & 700 & 1,500 & Yes \\
\hline Exercise books & & 800 & 2,000 & Yes \\
\hline $\begin{array}{c}\text { Fees for compulsory } \\
\text { extra activities }\end{array}$ & & 100 & 400 & Yes \\
\hline Teacher motivation & & 500 & 500 & Yes \\
\hline Examination fees & 600 & 450 & 1,250 & Yes \\
\hline $\begin{array}{l}\text { Total costs classified } \\
\text { under education in } \\
\text { national statistics } \\
\text { (Yes in last column) }\end{array}$ & 5,350 & 5,000 & 14,500 & \\
\hline $\begin{array}{l}\text { Number of years in } \\
\text { each level }\end{array}$ & 2 & 8 & 4 & \\
\hline Total cost $\mathrm{x}$ years & 10,700 & 40,000 & 58,000 & 108,700 \\
\hline $\begin{array}{l}\text { Average cost per child } \\
\text { per year assuming } \\
\text { parents responsible } \\
\text { for children for } 18 \\
\text { years }\end{array}$ & & & & $\begin{array}{l}108,700 \div \\
18=6,039\end{array}$ \\
\hline $\begin{array}{l}\text { Average cost per month } \\
\text { for reference family } \\
\text { with } 3 \text { children }\end{array}$ & & & & $\begin{array}{l}6,039 \times 3 \div \\
12=1,509\end{array}$ \\
\hline
\end{tabular}




\section{NOTES}

1. According to the World Bank (2016), the net primary school enrollment ratio is the 'ratio of children of the official primary school age who are enrolled in primary school to the total population of the official primary school age.' Net secondary enrollment ratio is the 'ratio of children of the official secondary school age who are enrolled in secondary school to the population of the official secondary school age.' The gross enrollment rate is the 'ratio of all children attending primary school to the number of children of primary school age.' In places where many students repeat grades, the gross enrollment rate can be misleading, and therefore the net enrollment rate is preferred.

2. The reason why education expenditures are classified as they are in COICOP is that COICOP is mainly concerned with measuring inflation, and it is felt that inflation for school uniforms is likely to be similar to inflation for other types of clothing, inflation for school transport is likely to be similar to inflation for other types of transport, and so on.

3. In addition to tuition fees, Kenya includes the following in education expenditures: 'books \& other materials, uniform, boarding fees, transport, contribution for school building or maintenance, extra tuition fees, examination fees, PTA \& other related fees, pocket money \& shopping, other expenses' (KNBS, 2007, p. 38). Vietnam includes uniforms, textbooks, study tools, school fund, extra classes, and tutoring (Vietnam Government, 2012).

4. Only $10.6 \%$ of primary school students attend a private school and only $12.7 \%$ of secondary school children attend a private school according to World Bank's World Development Indicators. 